Received 12 September 1996; accepted 13 May 1997.

de Gennes, P. G. Scaling Concepts in Polymer Physics (Cornell Univ. Press, Ithaca, NY, 1979).

2. Doi, M. \& Edwards, S. The Theory of Polymer Dynamics (Clarendon, Oxford, 1986).

. Zimm, B. H. Dynamics of polymer molecules in dilute solution: viscoelasticity, flow birefringence and dielectric loss. J. Chem. Phys. 24, 269-278 (1956).

4. Kirkwood, J. \& Riseman, J. The intrinsic viscosities and diffusion constants of flexible macromolecule in solution. J. Chem. Phys. 16, 565-573 (1948).

5. Perkins, T., Quake, S., Smith, D. \& Chu, S. Relaxation of a single DNA molecule observed by optical microscopy. Science 264, 822-826 (1994)

6. Pecora, R. DNA-A model-compound for solution studies of macromolecules. Science 251, 893-898 (1991).

7. Sorlie, S. \& Pecora, R. A dynamic light-scattering study of 4 DNA restriction fragments. Macromolecules 23, 487-497 (1990)

8. Adam, M. \& Delsanti, M. Dynamical properties of polymer solutions in good solvent by Rayleigh scattering experiments. Macromolecules 10, 1229-1237 (1977).

9. Sahouani, H. \& Lodge, T. P. Onset of excluded-volume effects in chain dynamics. Macromolecules 25, 5632-5642 (1992)

10. Amelar, S. et al. Dynamic properties of low and moderate molecular-weight polystyrenes at infinite dilution. Macromolecules 24, 3505-3516 (1991).

11. Sammler, R. L. et al. Polydispersity effects on dilute-solution dynamic properties of linear homopolymers. Macromolecules 23, 2388-2396 (1990).

12. Johnson, R., Schrag, J. \& Ferry, J. Infinite-dilution viscoelastic properties of polystyrene in $\theta$-solvents and good solvents. Polym. J. 1, 742-749 (1970).

13. Hong, M. K. et al. Internal dynamics of DNA probed by transient electric birefringence. Phys. Rev. Lett. 68, 1430-1433 (1992)

14. Lewis, R., Pecora, R. \& Eden, D. Transient electric birefringence measurements of the rotational and internal bending modes in monodisperse DNA fragments. Macromolecules 19, 134-139 (1986).

15. Watanabe, H., Yao, M. \& Osaki, K. Comparison of dielectric and viscoelastic relaxation behavior of polyisoprene solutions-coherence in subchain motion. Macromolecules 29, 97-103 (1996).

16. Watanabe, H., Yamada, H. \& Urakawa, O. Dielectric-relaxation of dipole-inverted cis-polyisoprene solutions. Macromolecules 28, 6443-6453 (1995)

17. Watanabe, H., Urukawa, O. \& Kotaka, T. Slow dielectric-relaxation of entangled linear cis-polyisoprenes with asymmetrically inverted dipoles. 1. Bulk systems. Macromolecules 26, 5073-5083 (1993).

18. Ashkin, A., Dziedzic, J., Bjorkholm, J. \& Chu, S. Observation of a single-beam gradient force optica trap for dielectric particles. Opt. Lett. 11, 288-290 (1986).

19. Marciano, Y. \& Brochard-Wyart, F. Normal-modes of stretched polymer-chains. Macromolecules 28 985-990 (1995).

20. Press, W., Teukolsky, S., Vetterling, W. \& Flannery, P. Numerical Recipes (Cambridge Univ. Press, New York, 1994).

21. Zimm, B., Roe, G. \& Epstein, L. Solution of a characteristic value problem for the theory of chain molecules. J. Chem. Phys. 24, 279-280 (1956).

22. De Gennes, P. G. Coil-stretch transition of dilute flexible polymers under ultrahigh velocity gradients. J. Chem. Phys. 60, 5030-5042 (1974).

23. Smith, D., Perkins, T. \& Chu, S. Dynamical scaling of DNA diffusion-coefficients. Macromolecules 29, 1372-1373 (1996)

24. Pincus, P. Excluded volume effects and stretched polymer chains. Macromolecules 9, 386-388 (1976). 25. Pincus, P. Dynamics of stretched polymer chains. Macromolecules 10, 210-213 (1977).

Acknowledgements. We thank T. T. Perkins and D. E. Smith for contributions and discussions in the early stages of this work, and B. Zimm, R. Larson, T. Lodge, G. Fuller, E. Shaqfeh, S. Doniach and W. Volkmuth for discussions. This work was supported in part by the Air Force Office of Scientific Research, the National Science Foundation, and the Human Frontier Science Program. S.R.Q. was supported in part by an NSF fellowship.

Correspondence and requests for materials should be addressed to S.C. (e-mail: schu@leland.stanford edu).

\section{Multiple episodes of aridity in southern Africa since the last interglacial period}

\section{Stephen Stokes ${ }^{\star} \dagger$, David S. G. Thomas $\ddagger$ \& Richard Washington*}

${ }^{*}$ School of Geography, University of Oxford, Mansfield Road, Oxford OX1 3QJ, UK

$\dagger$ Research Laboratory for Archaeology and the History of Art, University of Oxford, Mansfield Road, Oxford OX1 3TB, UK $\ddagger$ Sheffield Centre for International Drylands Research, Department of Geography, University of Sheffield, Sheffield S10 2TN, UK

There is generally a dearth of evidence of the nature of Quaternary climate change within desert systems, which has limited previous interpretations of past environmental change at low latitudes. The Last Glacial Maximum has previously been identified as the peak of Late Quaternary aridity, when desert systems expanded to five times their present extent ${ }^{1-3}$, and low-latitude aridity has been described for previous glaciations ${ }^{4}$. But little evidence has been derived directly for large desert basins, particularly southern
Africa. Here we report new chronological (optical dating) evidence of arid episodes recorded in aeolian sediments from the Mega Kalahari sand sea. Episodic aeolian activity is recorded at the northeastern desert margin, whereas more sustained activity is evident from the southwestern desert core. Several significant arid events are apparent since the last interglacial period, with dune-building (arid) phases at $\sim 95-115,41-46,20-26$ and 9-16 kyr before present. Existing atmospheric general circulation model simulations and independent palaeoclimate data indicate that the changes in aridity are related to changes in the northeastsouthwest summer rainfall gradient, which are in turn related to sea surface temperatures in the southeastern Atlantic Ocean.

The $2.5 \times 10^{6} \mathrm{~km}^{2}$ Mega Kalahari is the world's most continuous area of aeolian sand sea which is dominated by variably degraded and pedogenically modified, currently inactive, linear dunes ${ }^{5}$ (Fig. 1). The development and evolution of the extensive Kalahari linear dune systems has not until now been directly dated. Phases of aridity and dune development have previously been inferred from gaps within subcontinental humid chronologies ${ }^{6,7}$, or by assumed mirroring of Northern Hemisphere conditions ${ }^{8}$. We have determined the timing of dune building and associated palaeoaridity along the present day northeast-southwest summer rainfall gradient by optically dating ${ }^{9}$ dune sediments from geographically and morphologically wide-ranging aeolian deposits. Past changes in aeolian dynamism is assumed to be related to shifting rainfall intensities along the gradient (Fig. 1).

The effect of this northeast-southwest rainfall gradient on aeolian activity provides an opportunity to determine the sensitivity of the climate system to changing boundary conditions since the last interglacial. The climatology of this gradient is an infrequently studied element of the general circulation of the subcontinent, yet one that is accurately captured in all present-day leading general circulation models ${ }^{10,11}$. It originates from the Earth's largest crosscontinental zonal asymmetry of tropical convection; the intertropical convergence zone (ITCZ) in the southwestern Indian Ocean occupies the most southerly location of any ocean at $23^{\circ} \mathrm{S}$, whereas tropical convection in the eastern Atlantic Ocean is seldom found south of $5^{\circ} \mathrm{N}$ (ref. 11). Convection over southern Africa aligns almost meridionally over the subcontinent. Differences in the latitude of convection in the adjacent oceans relates directly to sea surface temperatures (SSTs).

The southwestern Indian Ocean is the warmest ocean at $23^{\circ} \mathrm{S}$ whereas the southeastern Atlantic is the coldest (present-day January mean of 27.5 and $21.6{ }^{\circ} \mathrm{C}$, respectively). The extreme SST contrast across the subcontinent determines the southern African rainfall gradient (Fig. 1). Wetter conditions east of the Kalahari result from disturbances in the tropical easterlies associated with the Mascarene anticyclone. Westward propagation of easterly waves off the African subcontinent is blocked by cold stable air overlying the Benguela Current. Conditions west of the wave axis are therefore dry. Intense subsidence into subtropical anticyclones dominate the climatology of the austral winter, ensuring aridity. The elevated southern African land mass $(2,000 \mathrm{~m})$ cools through longwave emission, thereby providing an interhemispheric sink for Asian monsoon outflow. Few deserts provide a suite of controls on the rainfall regime as diverse as the Kalahari.

Although the controls on aeolian sedimentation, particularly in the case of linear dune development ${ }^{12}$, may be complex we believe that our chronology of dune construction reflects periods of regionally enhanced aridity. In the northeastern Kalahari, mean rainfall today exceeds $400 \mathrm{~mm} \mathrm{yr}^{-1}$, and the pedogenically modified and vegetated surfaces of degraded linear dunes prohibits aeolian activity. In the southwestern Kalahari the present mean annual rainfall is $150-200 \mathrm{~mm}$. Episodic, localized aeolian activity is confined to dune crests and controlled by variations in vegetation cover induced by interannual variations in rainfall and intensive grazing, but is in any case significantly restricted by present-day low 
wind energy conditions ${ }^{13}$. Conditions throughout the Kalahari today, therefore, are neither arid nor windy enough to permit wholesale dune construction or reworking; the southwestern region is, however, somewhat closer to a threshold of dune reactivation than the northeastern region.

Samples for optical dating 9 (Table 1) were collected from linear dunes and ancillary aeolian bedforms (mainly lunette dunes and dune patches) from the two major dunefields in the sand sea (Fig. 1). Where feasible, a sequence of vertically spaced samples was analysed, facilitating assessments of the rate and continuity of aeolian accumulation. The four types of aeolian deposit sampled in the southwestern Kalahari yielded contrasting age assessments spanning the past in $30 \mathrm{kyr}$ (Fig. 2; Table 1). Samples from basal sediments within linear dunes consistently yielded ages exceeding $20 \mathrm{kyr}$, whereas analyses on sands from the body of dunes describing the main linear forms of the area generally indicate depositional ages in the range 10-20 kyr. Samples 945/1 \& 948/1 from the basal sands at the contact of non-aeolian strata demonstrate that aeolian activity from 22 to $28 \mathrm{kyr}$ ago operated to the full depth of the sand sea, precluding the preservation of older dunes. The maximum extent of the Kalahari to the southwest is constrained by three optical dates for a dune which invaded the Orange River valley at $\sim 13.2 \pm 1.5 \mathrm{kyr}$ ago. Based on palaeoecological evidence ${ }^{7,14}$, we infer either reduction or cessation of dune activity in the periods $22-16$ and 6-10 kyr ago.
Dune construction during the Holocene epoch appears to have been less intensive, resulting only in localized dune deposits. MidHolocene ( $\sim 6 \mathrm{kyr}$ ago $)$ aridity is demonstrated from superficial reticulate dunes (site 946; Table 1), and Late Holocene aridity ( $\leqslant 2$ kyr ago) from lunette deposition (site 949), and localized disturbance patches (site 947). The timing of the three post-LGM periods of aridity accord well with gaps in the northern Cape humid chronologies ${ }^{15}$.

Aeolian geomorphic units sampled within the northeastern Kalahari comprised either weathered and degraded linear dunes or poorly defined dune mounts (Table 1). In contrast to the southwest, linear dunes in the northeast are larger and substantially older features, and there is little evidence for Holocene deposition. Detailed analysis of a 6-m-deep linear dune profile delineated major phases of dune construction at $\sim 95-115,41-46$ and $20-26 \mathrm{kyr}$ ago (Fig. 2c). The sequence is suggestive of relatively short-lived ( $\sim 5-20 \mathrm{kyr})$ periods of non-deposition, landscape stability and increased net moisture which are recorded as subtle changes in pedogenesis and organic-matter content. Limited late glacial and Early Holocene aeolian activity $(10-16 \mathrm{kyr}$ ago $)$ is also identified in this area, typically superimposed on the principal linear dune pattern. Independent palaeoenvironmental evidence ${ }^{16,17}$ supporting increases in moisture during the period $20-15 \mathrm{kyr}$ ago implies that this latest event is separate from the $20-26 \mathrm{kyr}$ event. Middle and later Holocene dune reactivation is absent from the area.

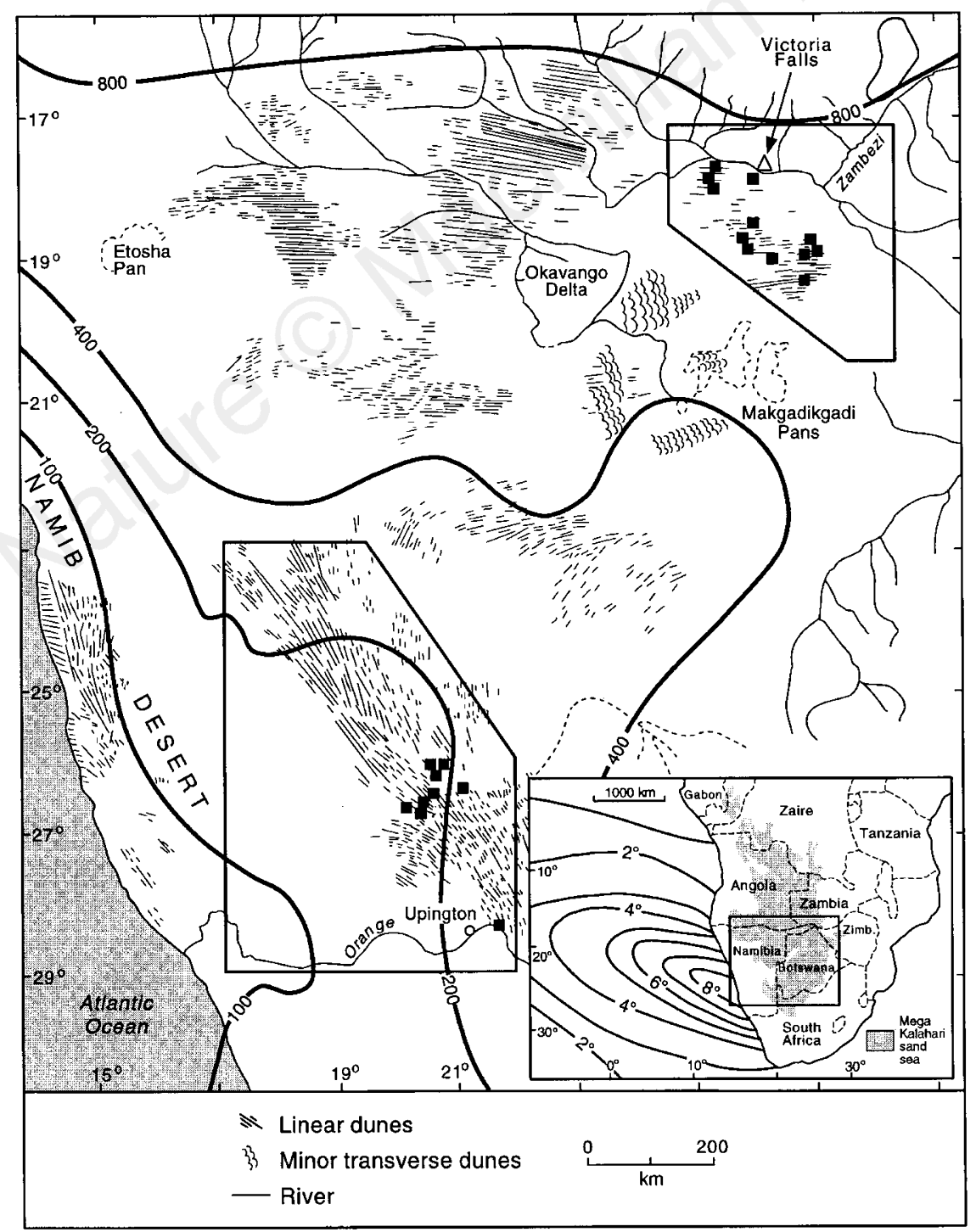

Figure 1 Sample sites within the linear dune systems are shown by filled squares in the two boxed areas (which are shown in detail in Fig. 2). Isohyets (contours) show present-day mean annual rainfall in the region and demonstrate the northeast-southwest regional rainfall gradient in the continental interior. Intense present-day aridity and true desert conditions are restricted to the geographically isolated coastal Namib Desert. Inset, location of the study area in the context of the $2.5 \times 10^{6} \mathrm{~km}^{2}$ Mega Kalahari sand sea and symmetrical Indian/Atlantic Ocean mean (1951-80) temperature differences $\left({ }^{\circ} \mathrm{C}\right)$ for the January period. The temperature-difference contours show the cold anomaly of the Atlantic Ocean relative to the Indian Ocean. Cold Atlantic water is maintained through 'symbiosis' between ocean and atmosphere; the subtropical oceanic gyre is driven through wind stress by the South Atlantic anticyclone which benefits, in turn, from the cold ocean surface it helps to maintain. 
In both the northeastern and southwestern Kalahari there is evidence of extensive linear dune field construction (persistent aridity) during the later Quaternary, which was succeeded in the southwest by episodes of minor, spatially confined, dune emplacement. The record of linear dune development in the northeast, where major dune construction periods extend to the Pleistocene/ Holocene boundary, is of considerably greater antiquity than that preserved in the southwest.

A preponderance of studies of North African Quaternary palaeoclimates based on terrestrial and oceanic evidence have failed to identify a single forcing mechanism of climate changes. Instead, the preserved records support influences of both precessional variations at the 19-23 kyr periodicities enhancing summer monsoonal rainfall regimes-particularly before the onset of high-latitude Quaternary glacial conditions ${ }^{18}$ — and the 41 - and 100 -kyr obliquity and eccentricity periodicities as influencing continental aridity, modulated at least in part by related changes (reductions) in SSTs ${ }^{4,19,20}$. Given the paucity of high-resolution marine records for the oceans adjacent to Southern Africa, theories of large-scale forcing of southern African climates have focused on generally more recent ( $\leqslant 25 \mathrm{kyr}$ ), sparsely distributed, discontinuous terrestrial records and some coastal sequences ${ }^{21,22}$.

Changes in the moisture regime which have influenced dune reactivations relate to changes in the extent of summer precipitation, which we interpret as changes in convection along the northeast-southwest gradient. These, in turn, relate to the controls on this gradient, such as SSTs, identified earlier. To determine the sensitivity of this gradient to SSTs, we pursued a set of GCM experiments where the United Kingdom Meteorological Office (UKMO) atmospheric GCM HADAM2A (resolution $2.5^{\circ}$ latitude,

Table 1 Summary data for samples

\begin{tabular}{|c|c|c|c|c|c|c|c|c|c|c|c|}
\hline \multirow[t]{2}{*}{ Sample } & \multirow{2}{*}{$\begin{array}{l}\text { Lat. } \\
\text { (S) }\end{array}$} & \multirow{2}{*}{$\begin{array}{l}\text { Long. } \\
\text { (E) }\end{array}$} & \multirow[t]{2}{*}{ Description of locality } & \multirow{2}{*}{$\begin{array}{l}\text { Sample } \\
\text { depth (m) }\end{array}$} & \multicolumn{3}{|c|}{ Radioactivity data } & \multirow{2}{*}{$\begin{array}{c}D_{\text {cosmic }} \\
\left(\mathrm{Gy} \mathrm{kyr}^{-1}\right)\end{array}$} & \multirow{2}{*}{$\begin{array}{l}\text { Dose rate } \\
\left(\text { Gy kyr } r^{-1}\right)\end{array}$} & \multirow{2}{*}{$\begin{array}{l}\text { Palaeodose } \\
\text { (Gy) }\end{array}$} & \multirow{2}{*}{$\begin{array}{l}\text { Age } \\
(\mathrm{kyr})\end{array}$} \\
\hline & & & & & $\mathrm{K}_{2} \mathrm{O}(\%)$ & Th (p.p.m.) & U (p.p.m.) & & & & \\
\hline \multicolumn{12}{|c|}{ Northeastern Kalahari } \\
\hline $890 / 2$ & $18^{\circ} 45^{\prime}$ & $25^{\circ} 45^{\prime}$ & Linear dune & 2.0 & $0.08 \pm 0.01$ & $1.4 \pm 0.10$ & $0.7 \pm 0.06$ & 0.14 & $0.48 \pm 0.05$ & $10.5 \pm 1.1$ & $22 \pm 3$ \\
\hline $891 / 1$ & $18^{\circ} 50^{\prime}$ & $25^{\circ} 50^{\prime}$ & Linear dune & 1.8 & $0.17 \pm 0.02$ & $1.3 \pm 0.10$ & $0.5 \pm 0.06$ & 0.18 & $0.53 \pm 0.05$ & $13.1 \pm 1.5$ & $25 \pm 4$ \\
\hline $891 / 2$ & $18^{\circ} 50^{\prime}$ & $25^{\circ} 50^{\prime}$ & Linear dune & 0.9 & $0.17 \pm 0.02$ & $1.2 \pm 0.10$ & $0.5 \pm 0.06$ & 0.17 & $0.51 \pm 0.05$ & $12.6 \pm 1.2$ & $25 \pm 3$ \\
\hline $892 / 1$ & $19^{\circ} 15^{\prime}$ & $26^{\circ} 22^{\prime}$ & Linear dune & 1.2 & $0.07 \pm 0.03$ & $1.7 \pm 0.10$ & $0.6 \pm 0.07$ & 0.18 & $0.51 \pm 0.09$ & $11.0 \pm 1.4$ & $22 \pm 5$ \\
\hline $892 / 2$ & $19^{\circ} 15^{\prime}$ & $26^{\circ} 22^{\prime}$ & Linear dune & 0.7 & $0.07 \pm 0.02$ & $1.6 \pm 0.10$ & $0.6 \pm 0.07$ & 0.18 & $0.50 \pm 0.08$ & $7.0 \pm 1.4$ & $14 \pm 4$ \\
\hline $894 / 1$ & $18^{\circ} 55^{\prime}$ & $26^{\circ} 41^{\prime}$ & Superficial dune mound & 1.2 & $0.07 \pm 0.03$ & $2.5 \pm 0.10$ & $1.0 \pm 0.08$ & 0.19 & $0.67 \pm 0.16$ & $7.1 \pm 0.4$ & $10.6 \pm 3$ \\
\hline $895 / 1$ & $18^{\circ} 43^{\prime}$ & $26^{\circ} 57^{\prime}$ & Minor linear dune & 1.0 & $0.10 \pm 0.03$ & $1.5 \pm 0.10$ & $2.3 \pm 0.10$ & 0.18 & $0.91 \pm 0.17$ & $13.3 \pm 3.0$ & $14.6 \pm 4$ \\
\hline $896 / 1$ & $18^{\circ} 00^{\prime}$ & $25^{\circ} 50^{\prime}$ & Linear dune & 1.6 & $0.27 \pm 0.05$ & $2.6 \pm 0.10$ & $0.7 \pm 0.08$ & 0.18 & $0.75 \pm 0.09$ & $15.7 \pm 5.6$ & $21 \pm 8$ \\
\hline $950 / 1$ & $17^{\circ} 58^{\prime}$ & $25^{\circ} 38^{\prime}$ & Linear dune & 1.25 & $0.03 \pm 0.001$ & $1.8 \pm 0.17$ & $0.6 \pm 0.13$ & 0.17 & $0.47 \pm 0.05$ & $17.5 \pm 3.4$ & $37 \pm 8$ \\
\hline $951 / 1$ & $18^{\circ} 02^{\prime}$ & $25^{\circ} 41^{\prime}$ & Linear dune & 1.23 & $0.05 \pm 0.002$ & $1.8 \pm 0.17$ & $0.7 \pm 0.14$ & 0.17 & $0.51 \pm 0.05$ & $16.1 \pm 2.3$ & $32 \pm 6$ \\
\hline $952 / 1$ & $17^{\circ} 55^{\prime}$ & $25^{\circ} 28^{\prime}$ & Extensively degraded dune mound & 4.5 & $0.03 \pm 0.001$ & $1.8 \pm 0.17$ & $0.7 \pm 0.13$ & 0.17 & $0.49 \pm 0.05$ & $37.8 \pm 4.6$ & $77 \pm 12$ \\
\hline $952 / 2$ & $17^{\circ} 55^{\prime}$ & $25^{\circ} 28^{\prime}$ & Extensively degraded dune mound & 3.0 & $0.03 \pm 0.001$ & $1.9 \pm 0.18$ & $0.6 \pm 0.13$ & 0.17 & $0.47 \pm 0.05$ & $24.6 \pm 2.9$ & $52 \pm 8$ \\
\hline $952 / 3$ & $17^{\circ} 55^{\prime}$ & $25^{\circ} 28^{\prime}$ & Extensively degraded dune mound & 1.8 & $0.03 \pm 0.001$ & $1.5 \pm 0.17$ & $0.5 \pm 0.13$ & 0.18 & $0.43 \pm 0.05$ & $71 \pm 11$ & $164 \pm 32$ \\
\hline $1003 / 1$ & $18^{\circ} 35^{\prime}$ & $25^{\circ} 54^{\prime}$ & Linear dune & 1.0 & $0.41 \pm 0.02$ & $2.3 \pm 0.21$ & $0.8 \pm 0.13$ & 0.17 & $0.85 \pm 0.09$ & $12.7 \pm 1.5$ & $15 \pm 2$ \\
\hline $1003 / 2$ & $18^{\circ} 35^{\prime}$ & $25^{\circ} 54^{\prime}$ & Linear dune & 2.0 & $0.41 \pm 0.02$ & $2.8 \pm 0.22$ & $1.1 \pm 0.15$ & 0.17 & $0.96 \pm 0.09$ & $22.0 \pm 1.9$ & $23 \pm 3$ \\
\hline 1004/A & $19^{\circ} 23^{\prime}$ & $26^{\circ} 45^{\prime}$ & Linear dune & 0.5 & $0.17 \pm 0.01$ & $1.0 \pm 0.15$ & $0.5 \pm 0.10$ & 0.21 & $0.54 \pm 0.06$ & $9.6 \pm 2.5$ & $18 \pm 5$ \\
\hline 1004/B & $19^{\circ} 23^{\prime}$ & $26^{\circ} 45^{\prime}$ & Linear dune & 1.0 & $0.2 \pm 0.01$ & $1.3 \pm 0.18$ & $0.6 \pm 0.10$ & 0.18 & $0.57 \pm 0.06$ & $13.0 \pm 2.5$ & $23 \pm 5$ \\
\hline $1004 / C$ & $19^{\circ} 23^{\prime}$ & $26^{\circ} 45^{\prime}$ & Linear dune & 1.5 & $0.2 \pm 0.01$ & $1.4 \pm 0.24$ & $0.7 \pm 0.12$ & 0.16 & $0.58 \pm 0.07$ & $16.2 \pm 2.5$ & $28 \pm 5$ \\
\hline 1004/D & $19^{\circ} 23^{\prime}$ & $26^{\circ} 45^{\prime}$ & Linear dune & 2.0 & $0.17 \pm 0.01$ & $1.6 \pm 0.24$ & $0.5 \pm 0.11$ & 0.15 & $0.52 \pm 0.07$ & $22.2 \pm 3.3$ & $43 \pm 9$ \\
\hline 1004/E & $19^{\circ} 23^{\prime}$ & $26^{\circ} 45^{\prime}$ & Linear dune & 2.5 & $0.17 \pm 0.01$ & $1.5 \pm 0.24$ & $0.8 \pm 0.12$ & 0.14 & $0.57 \pm 0.07$ & $24.3 \pm 3.5$ & $43 \pm 8$ \\
\hline 1004/F & $19^{\circ} 23^{\prime}$ & $26^{\circ} 45^{\prime}$ & Linear dune & 3.0 & $0.18 \pm 0.01$ & $1.6 \pm 0.22$ & $0.7 \pm 0.12$ & 0.13 & $0.55 \pm 0.07$ & $25.7 \pm 2.8$ & $46 \pm 8$ \\
\hline $1004 / G$ & $18^{\circ} 23^{\prime}$ & $26^{\circ} 45^{\prime}$ & Linear dune & 3.5 & $0.19 \pm 0.01$ & $1.6 \pm 0.16$ & $0.7 \pm 0.10$ & 0.13 & $0.56 \pm 0.05$ & $21.8 \pm 1.8$ & $39 \pm 5$ \\
\hline $1004 / \mathrm{H}$ & $19^{\circ} 23^{\prime}$ & $26^{\circ} 45^{\prime}$ & Linear dune & 4.0 & $0.16 \pm 0.01$ & $1.6 \pm 0.18$ & $0.7 \pm 0.09$ & 0.12 & $0.53 \pm 0.05$ & $28.0 \pm 2.9$ & $53 \pm 8$ \\
\hline $1004 / 1$ & $19^{\circ} 23^{\prime}$ & $26^{\circ} 45^{\prime}$ & Linear dune & 4.5 & $0.29 \pm 0.01$ & $1.5 \pm 0.17$ & $0.6 \pm 0.09$ & 0.11 & $0.59 \pm 0.07$ & $26.7 \pm 3.1$ & $46 \pm 7$ \\
\hline $1004 / J$ & $19^{\circ} 23^{\prime}$ & $26^{\circ} 45^{\prime}$ & Linear dune & 5.0 & $0.16 \pm 0.01$ & $1.9 \pm 0.22$ & $0.6 \pm 0.11$ & 0.10 & $0.51 \pm 0.06$ & $52.4 \pm 5.5$ & $103 \pm 17$ \\
\hline $1004 / \mathrm{K}$ & $19^{\circ} 23^{\prime}$ & $26^{\circ} 45^{\prime}$ & Linear dune & 5.5 & $0.17 \pm 0.01$ & $1.6 \pm 0.17$ & $0.6 \pm 0.10$ & 0.10 & $0.49 \pm 0.06$ & $54.7 \pm 5.9$ & $112 \pm 18$ \\
\hline 1004/L & $19^{\circ} 23^{\prime}$ & $26^{\circ} 45^{\prime}$ & Linear dune & 6.0 & $0.21 \pm 0.01$ & $1.7 \pm 0.17$ & $0.6 \pm 0.10$ & 0.09 & $0.52 \pm 0.06$ & $53.4 \pm 6.5$ & $102 \pm 18$ \\
\hline $1005 / A$ & $15^{\circ} 51^{\prime}$ & $26^{\circ} 55^{\prime}$ & Linear dune & 0.5 & $0.08 \pm 0.003$ & $1.2 \pm 0.11$ & $0.5 \pm 0.07$ & 0.20 & $0.46 \pm 0.03$ & $4.3 \pm 0.8$ & $9 \pm 2$ \\
\hline $1005 / B$ & $15^{\circ} 51^{\prime}$ & $26^{\circ} 55^{\prime}$ & Linear dune & 1.0 & $0.03 \pm 0.003$ & $1.5 \pm 0.15$ & $0.7 \pm 0.07$ & 0.18 & $0.50 \pm 0.06$ & $14.1 \pm 2.2$ & $28 \pm 6$ \\
\hline $1005 / C$ & $15^{\circ} 51^{\prime}$ & $26^{\circ} 55^{\prime}$ & Linear dune & 1.5 & $0.08 \pm 0.003$ & $1.6 \pm 0.19$ & $0.7 \pm 0.11$ & 0.16 & $0.50 \pm 0.05$ & $10.1 \pm 2.1$ & $\begin{array}{l}20 \pm 0 \\
20 \pm 5\end{array}$ \\
\hline 1005/D & $15^{\circ} 51^{\prime}$ & $26^{\circ} 55^{\prime}$ & Linear dune & 2.0 & $0.08 \pm 0.003$ & $1.3 \pm 0.19$ & $0.7 \pm 0.13$ & 0.14 & $0.46 \pm 0.05$ & $19.4 \pm 2.0$ & $42 \pm 7$ \\
\hline $1005 / E$ & $15^{\circ} 51^{\prime}$ & $26^{\circ} 55^{\prime}$ & Linear dune & 2.5 & $0.09 \pm 0.004$ & $1.5 \pm 0.18$ & $1.0 \pm 0.12$ & 0.14 & $0.56 \pm 0.05$ & $16.6 \pm 1.8$ & $30 \pm 4$ \\
\hline $1005 / F$ & $15^{\circ} 51^{\prime}$ & $26^{\circ} 55^{\prime}$ & Linear dune & 3.0 & $0.09 \pm 0.004$ & $1.5 \pm 0.16$ & $0.7 \pm 0.11$ & 0.13 & $0.48 \pm 0.05$ & $18.9 \pm 2.1$ & $40 \pm 6$ \\
\hline \multicolumn{12}{|c|}{ Southwestern Kalahari } \\
\hline $942 / 1$ & $28^{\circ} 24^{\prime}$ & $21^{\circ} 30^{\prime}$ & Linear dune & 3.5 & $0.08 \pm 0.02$ & $1.7 \pm 0.18$ & $0.4 \pm 0.12$ & 0.13 & $0.79 \pm 0.15$ & $11.0 \pm 1.0$ & $14 \pm 3$ \\
\hline $942 / 2$ & $28^{\circ} 24^{\prime}$ & $21^{\circ} 30^{\prime}$ & Linear dune & 2.5 & $0.58 \pm 0.02$ & $2.0 \pm 0.20$ & $0.5 \pm 0.13$ & 0.14 & $0.86 \pm 0.15$ & $12.9 \pm 0.7$ & $15 \pm 3$ \\
\hline $942 / 3$ & $28^{\circ} 24^{\prime}$ & $21^{\circ} 30^{\prime}$ & Linear dune & 1.5 & $0.66 \pm 0.03$ & $2.5 \pm 0.20$ & $0.5 \pm 0.14$ & 0.16 & $0.98 \pm 0.18$ & $11.2 \pm 0.9$ & $12 \pm 2$ \\
\hline $943 / 1$ & $26^{\circ} 33^{\prime}$ & $20^{\circ} 35^{\prime}$ & Linear dune & 1.5 & $0.88 \pm 0.04$ & $1.0 \pm 0.16$ & $0.3 \pm 0.12$ & 0.17 & $1.00 \pm 0.27$ & $10.4 \pm 2.1$ & $10 \pm 4$ \\
\hline $944 / 1$ & $26^{\circ} 39^{\prime}$ & $20^{\circ} 36^{\prime}$ & Linear dune & 1.55 & $0.94 \pm 0.04$ & $1.5 \pm 0.17$ & $0.4 \pm 0.12$ & 0.14 & $1.08 \pm 0.23$ & $18.1 \pm 2.6$ & $17 \pm 4$ \\
\hline $945 / 1$ & $26^{\circ} 14^{\prime}$ & $20^{\circ} 36^{\prime}$ & Basal linear dune field sand & 1.75 & $0.78 \pm 0.03$ & $1.8 \pm 0.18$ & $0.5 \pm 0.13$ & 0.16 & $1.02 \pm 0.18$ & $23.5 \pm 3.6$ & $23 \pm 5$ \\
\hline $946 / 1$ & $26^{\circ} 27^{\prime}$ & $21^{\circ} 48^{\prime}$ & Recticulate dune overyling linear & 1.8 & $0.73 \pm 0.03$ & $1.4 \pm 0.16$ & $0.5 \pm 0.13$ & 0.15 & $0.94 \pm 0.17$ & $5.2 \pm 1.5$ & $6 \pm 2$ \\
\hline $946 \mathrm{~b} / 1$ & $26^{\circ} 27^{\prime}$ & $20^{\circ} 48^{\prime}$ & Linear dune & 1.5 & $0.78 \pm 0.03$ & $1.8 \pm 0.17$ & $0.4 \pm 0.12$ & 0.17 & $1.01 \pm 0.20$ & $26.8 \pm 5.3$ & $27 \pm 7$ \\
\hline $947 / 1$ & $26^{\circ} 07^{\prime}$ & $20^{\circ} 39^{\prime}$ & Hummocky dune patch & 1.0 & $0.36 \pm 0.01$ & $0.9 \pm 0.16$ & $0.2 \pm 0.10$ & 0.17 & $0.56 \pm 0.16$ & $1.0 \pm 10.3$ & $1.7 \pm 0.7$ \\
\hline $947 / 2$ & $26^{\circ} 07^{\prime}$ & $20^{\circ} 39^{\prime}$ & Hummocky dune patch & 1.0 & $0.51 \pm 0.02$ & $0.9 \pm 0.15$ & $0.3 \pm 0.11$ & 0.17 & $0.71 \pm 0.16$ & $1.0 \pm 0.3$ & $1.4 \pm 0.5$ \\
\hline $948 / 1$ & $26^{\circ} 31^{\prime}$ & $20^{\circ} 36^{\prime}$ & Basal linear dune field sand & 1.0 & $1.09 \pm 0.04$ & $2.6 \pm 0.23$ & $0.6 \pm 0.15$ & 0.19 & $1.37 \pm 0.24$ & $37.9 \pm 6.4$ & $28 \pm 7$ \\
\hline $949 / 2$ & $26^{\circ} 41^{\prime}$ & $20^{\circ} 10^{\prime}$ & Lunette & 1.0 & $1.17 \pm 0.05$ & $2.8 \pm 0.31$ & $0.8 \pm 0.20$ & 0.18 & $1.49 \pm 0.27$ & $2.1 \pm 0.1$ & $1.4 \pm 0.3$ \\
\hline $949 / 3$ & $26^{\circ} 41^{\prime}$ & $20^{\circ} 10^{\prime}$ & Lunette & 1.0 & $1.11 \pm 0.04$ & $3.2 \pm 0.23$ & $1.0 \pm 0.19$ & 0.22 & $1.56 \pm 0.20$ & $2.1 \pm 0.1$ & $1.4 \pm 0.2$ \\
\hline $949 / 4$ & $26^{\circ} 41^{\prime}$ & $20^{\circ} 10^{\prime}$ & Lunette & 1.0 & $1.39 \pm 0.06$ & $2.6 \pm 0.23$ & $0.7 \pm 0.16$ & 0.19 & $1.63 \pm 0.27$ & $1.8 \pm 0.1$ & $1.1 \pm 0.2$ \\
\hline $949 / 5$ & $26^{\circ} 41^{\prime}$ & $20^{\circ} 10^{\prime}$ & Lunette & 1.0 & $1.25 \pm 0.05$ & $2.5 \pm 0.24$ & $0.8 \pm 0.18$ & 0.23 & $1.58 \pm 0.25$ & $1.7 \pm 0.1$ & $1.1 \pm 0.2$ \\
\hline
\end{tabular}

Samples for optical dating were collected by hammering $500 \mathrm{~cm}^{3}$ light-proof PVC cylinders horizontally into the vertical walls of freshly cleaned exposures. All samples were processed under subdued red light. Each was wet-sieved (retaining $90-125 \mu \mathrm{m}$ size fraction) and immersed for $2 \mathrm{~d}$ in $1 \mathrm{~N} \mathrm{HCl}$, followed by $2 \mathrm{~d}$ immersion in $\mathrm{H}_{2} \mathrm{O}_{2}$. Heavy minerals (density $>2.72 \mathrm{~g}_{\mathrm{cm}}^{-3}$ )

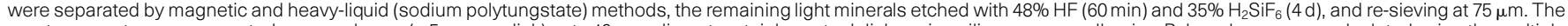

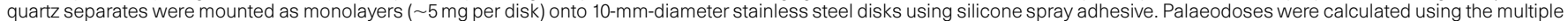
aliquot additive dose method ${ }^{27}$. Aliquots were exposed to an argon laser (Coherent $2 \mathrm{~W}, \lambda=514.5 \mathrm{~nm}$, power at sample $\sim 40 \mathrm{~mW}^{-2}$ ), optically stimulated luminescence (OSL) emissions detected using a Phillips $9635 \mathrm{Q}$ photomultiplier (PMT) filtered by BG-39 and Corning 7-51 glass filters. Aliquots were pre-heated either at $220^{\circ} \mathrm{C}$ for $5 \mathrm{~min}(949 / 2-949 / 5), 160^{\circ} \mathrm{C}$ for $16 \mathrm{~h}$, or both

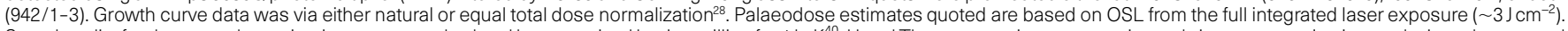
Sample splits for dose rate determinations were crushed and homogenized by ring milling for $1 \mathrm{~h} . \mathrm{K}^{40}, \mathrm{U}$ and Th concentrations were estimated via neutron activation analysis and converted to dose rates ${ }^{27}$. Saturation moisture content $(W)$ was estimated at 0.4 , and the estimated average moisture content over the burial period $(F)$ as 0.1 . $\left(\mathrm{Here} W=\left(\right.\right.$ Wt $\left.\mathrm{H}_{2} \mathrm{O}\right) /($ Wt sediment) and

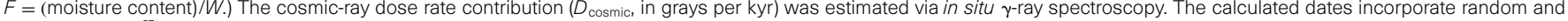
systematic error ${ }^{27}$, and are quoted to \pm 1 standard deviation. 
$3.75^{\circ}$ longitude, 19 vertical layers) was forced with observed SSTs for the period 1903-94. Empirical orthogonal functions (EOFs) of model austral summer (January-March) rainfall were calculated for the African land area and adjoining oceans using the ensemble average of four runs. An east-west dipole of rainfall, with centres over western southern Africa and the western Indian Ocean, captures $82 \%$ of rainfall variance of this broad region. The time coefficients of this EOF were correlated with global SSTs. The field shows a large coherent region of significant correlation in the southeastern Atlantic such that wet (dry) Kalahari conditions are associated with dry (wet) western Indian Ocean conditions, and positive (negative) SST anomalies in the southeastern Atlantic. Model circulation fields show the strengthening (weakening) of the South Atlantic anticyclone during Kalahari dry phases.

Evidence of moisture regimes since the last interglacial over southern Africa and the southern Indian Ocean are scarce, although available palaeodata provide some insights into changing moisture balances over the past $\sim 36 \mathrm{kyr}$ before present $\mathrm{t}^{6,23}$. These studies confirm shifts between relatively wet and dry conditions on a 5$20 \mathrm{kyr}$ timescale during this period (including the Holocene). The rainfall shift associated with the east-west dipole is consistent both with the Community Climate Model GCM experiments for $9 \mathrm{kyr}$ ago and the present ${ }^{24}$, and with elements of analogue models of southern African rainfall changes based on contemporary wet and dry spells ${ }^{6,7}$. Kalahari dry (wet) phases are controlled by variability in the SST gradient across southern Africa such that large (weak) SST gradients lead to stationary easterly disturbances east (over) of the African landmass and eastward encroachment (westward retreat) of the South Atlantic anticyclone. SST estimates from ocean core data ${ }^{25}$ reveals that since the last interglacial (marine

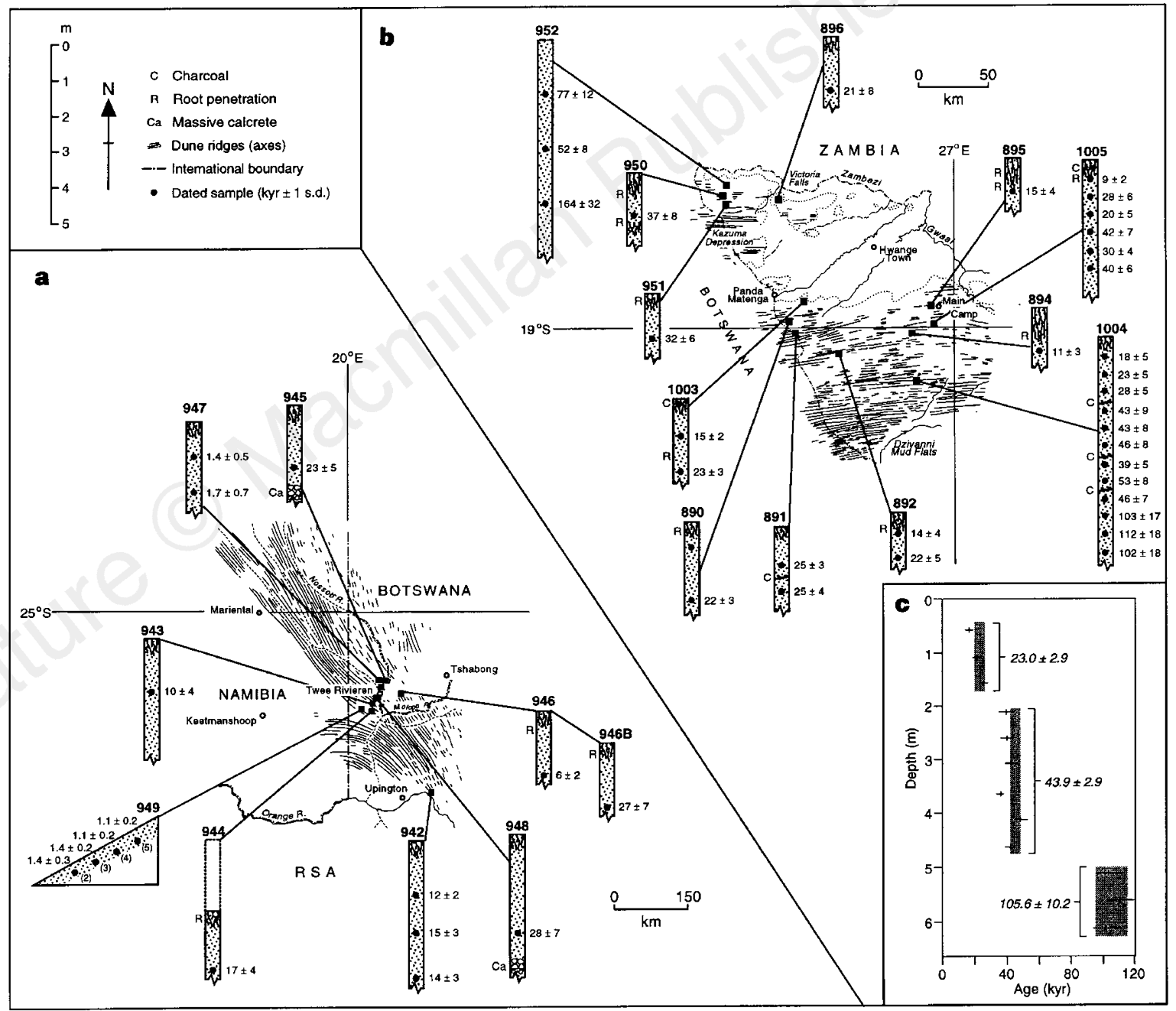

Figure 2 Summary stratigraphic and chronological data for dune sites: a, southwestern Kalahari; b, northeastern Kalahari; c, summary of optical dates and inferred aeolian depositional phases for site 1004 from the northeastern Kalahari (weighted average and standard deviations for grouped samples are provided). Note that different scales are used in $\mathbf{a}$ and $\mathbf{b}$. Samples collected from degraded dune forms near basal massive calcretes at sites 945 and 948 provide the oldest ages in the southwestern Kalahari, in addition to the age from site $946 \mathrm{~B}$ which was derived from a relatively weathered, fines-rich, linear dune. Analyses from sites 942 and 944 describe the main period of latest Pleistocene linear dune construction ( $\sim 10-20 \mathrm{kyr}$ ago) in the southwestern Kalahari which may have persistent into the Holocene (compare samples 943/1 and 946/1). The weighted average for site 942, where three statistically similar samples were collected in stratigraphic order, is $13.2 \pm 1.5 \mathrm{kyr}$ ( \pm 1 s.d.). Latest Holocene aeolian activity in the southwest is reflected in localized reactivation of hummocky dune forms (site 947) and lunette development (site 949). Age assessments for in the northeast are generally older than those from southwest. We use the record from site 1004 (c) as a master chronology for the area, from which three statistically distinct periods of dune activity are inferred spanning (at 1s.d.) 95-115, 41-46 and 20-26 kyr ago. Latest Pleistocene dates younger than 20 kyr derived from site 1003, 892 and 895 are not statistically significantly different from the most recent phase of activity from site 1004 . 
isotope stage 5e) Indian Ocean variance is low (for example, core $\mathrm{RC} 17-98,13.22^{\circ} \mathrm{S}, 65.60^{\circ} \mathrm{E} ; 0.18^{\circ} \mathrm{C}$ ) whereas that for the Atlantic is high (for example, core RC13-228, $22.33^{\circ} \mathrm{S}, 11.20^{\circ} \mathrm{E} ; 6.1^{\circ} \mathrm{C}$ ). Recent analyses of southeastern Atlantic marine sediments have identified repeated short-lived ( $\sim 5-10 \mathrm{kyr})$ periods of low SSTs ${ }^{26}$, three of which correspond to periods of enhanced aridity in the Mega Kalahari. We propose that changes to the SST gradient and hence the northeast-southwest rainfall gradient are likely to originate in the Atlantic.

We have shown that the Mega Kalahari sedimentary system has exhibited a complex response to changes in Quaternary climates. Similar complexity can be expected in other low-latitude areas where extensive dune systems are preserved, which could provide critical information for GCM validation and inter-regional comparison; but direct chronologies of the development of such areas have not yet been established.

Received 12 September 1996; accepted 23 May 1997.

1. Sarnthein, M. Sand deserts during glacial maximum and climatic optimum. Nature 272, 396-398 (1978).

2. Sarnthein, M. \& Koopman, B. Late Quaternary deep-sea record on northwest African dust supply and wind circulation. Palaeoecol. Afr. 12, 238-253 (1980).

3. Street-Perrott, F. A., Marchand, D. S., Roberts, N. \& Harrison, S. P. Global Lake Level Variations from 18,000 to 0 Years Ago: A Palaeoclimatic Analysis (Tech. Rep. TR046, US Dept of Energy, Washington DC, 1989)

4. de Menocal, P. B., Ruddiman, W. F. \& Pokras, E. M. Influences of high- and low-latitude processes on African terrestrial climate: Pleistocene eolian records from equatorial Atlantic ocean drilling program Site 663. Paleoceanography 8, 209-242 (1993).

Thomas, D. S. G. \& Shaw, P. A. The Kalahari Environment (Cambridge Univ. Press, 1991).

6. Cohen, A. L. \& Tyson, P. D. Sea-surface temperature fluctuations during the Holocene off the south coast of Africa: implications for terrestrial climate and rainfall. Holocene 5, 304-312 (1995).

Cockcroft, M. J., Wilkinson, M. J. \& Tyson, P. D. The application of a present day climatic model to the late Quaternary in Southern-Africa. Clim. Change 10, 161-181 (1987).

8. Van Zinderen Bakker, E. M. Comparison of late Quaternary climate change evolutions in the Sahara and the Namib-Kalahari region. Palaeoecol. Afr. 12, 381-394 (1980).

. Huntley, D. L., Godfrey-Smith, D. I. \& Thewalt, M. L. W. Optical dating of sediment. Nature 313, 257267 (1985).

10. Henderson-Sellers, A. \& Hansen, A.-M. Climate Change Atlas: Greenhouse Simulations from Model Evaluation for Climate Assessment (Kluwer, Dordrecht, 1995).

11. Schneider, S. H. (ed.) Encyclopedia of Climate and Weather (Oxford Univ. Press, New York, 1996).

12. Livingstone, I. \& Thomas, D. S. G. in The Dynamics and Environmental Context of Aeolian Sedimentary Systems (ed. Pye, K.) 91-103 (Geol. Soc. London, 1993).

13. Wiggs, G. F. S., Thomas, D. S. G., Bullard, J. E. \& Livingston, I. Dune mobility and vegetation cover in the southwest Kalahari desert. Earth Surf. Proc. Landf. 20, 515-530 (1995).

14. Thackeray, J. F. \& Lee Thorpe, J. A. Isotopic analysis of equid teeth from Wonderwerk Cave, Northern Cape Province, South Africa Palaeogeogr. Palaeoclimatol. Palaeoecol. 99, 141-150 (1992).

15. Partridge, T. C. et al. Late Pleistocene and Holocene climatic change in Southern Africa. S. Afr. J. Sci. 86, 302-306 (1990)

16. Shaw, P. A. \& Thomas, D. S. G. The Quaternary palaeoenvironmental history of the Kalahari, Southern Africa. J. Arid Environ. 32, 9-22 (1996).

17. Brookes, G. A., Cowart, J. B. \& Marais, E. Wet and dry periods in the southern African summer rainfall zone during the last $300 \mathrm{kyr}$ from speleothem, tufa and sand dune age data. Z. Fur. Geom. (in the press).

18. Bloemendal, J. \& de Menocal, P. Evidence for a change in the periodicity of tropical climate cycles at 2.4 Myr from whole-core magnetic susceptibility measurements. Nature 342, 897-900 (1989).

19. Street-Perrott, F. A. \& Perrott, R. A. Abrupt climate fluctuations in the tropics: the influence of Atlantic Ocean circulation. Nature 343, 607-612 (1990)

20. de Menocal, P. \& Rind, D. Sensitivity of Asian and African climate to variations in seasonal insolation, glacial ice cover, sea surface temperature, and Asian orography. J. Geophys. Res. 98, 7267-7287 (1993).

21. Avery, D. M. Late Pleistocene coastal environment of the southern Cape Province of South Africa micromammals from Klasies River mouth. J. Archaeol. Sci. 14, 405-412 (1987).

22. Miller, D. F., Yates, R. J., Parkington, J. E. \& Vogel, J. C. Radiocarbon-dated evidence relating to a midHolocene relative high sea-level on the south-western Cape Coast, South Africa. S. Afr. J. Sci. 89, 35 44 (1993).

23. Sifeddine, A. et al. La sédimentation organique lacustre en zone tropicale sud au cours des 36000 dernières années (Lac Tritrivakely, Madagascar). C. R. Acad. Sci., Ser. IIa 321, 385-391 (1995).

24. Kutzbach, J. E., Guetter, P. J., Behling, P. J. \& Selin, R. in Global Climates Since the Last Glacial Maximum (eds Wright, H. E. et al.) 24-93 (Univ. Minnesota Press, 1993).

25. Imbrie, J. \& Duffy, A. SPECMAP Archive (NOAA Palaeoclimatology Program, Natl Geophys. Dat Center, Boulder, CO, 1993)

26. Little, M. G. et al. Trade wind forcing of upwelling, seasonality, and Heinrich events as response to sub-Milankovitch climate variability. Paleoceanography (in the press).

27. Aitken, M. J. Thermoluminescence Dating (Academic, London, 1985).

28. Stokes, S. Optical dating of selected late Quaternary aeolian sediment from the southwestern United States. Thesis, Oxford Univ. (1994).

Acknowledgements. We thank P. Shaw and G. Haynes for discussions; M. Malifa, M. Moore, B. Adder P. O'Connor, G. Wiggs, E and K. Walker for technical and field assistance; P. Hayward for drafting assistance; G. A. Brookes, M. Little and D. Kroon for providing access to unpublished data; M. J. Aitken, A. K. Singhvi and C. K. Folland for advice on wider aspects of the research programme; and D. Sexton for help with model data. This work forms part of a wider project on southern African palaeoenvironments funded in part by the Trapnell Fund, the Universities of Oxford and Sheffield; R. Washington was supported by the DOE.

Correspondence and requests for materials should be addressed to S.S. (e-mail: stephen.stokes@ geography.ox.ac.uk).

\section{Sensitivity of earthquake cycles on the San Andreas fault to small changes in regional compression}

\author{
Chi-yuen Wang $*$ \& Yongen Cai $\dagger$
}

* Department of Geology \& Geophysics, University of California, Berkeley, California 94720, USA

$\dagger$ Department of Geology, Peking University, Beijing 100871, China

The current pattern of slip $^{1,2}$ within the San Andreas fault system in the San Francisco Bay area is distinctly different from the longterm slip pattern inferred from the geological record ${ }^{3,4}$. This difference is not surprising because geological data record the accumulated displacements over many earthquake cycles, whereas geodetic data reveal the present-day slip pattern. It is not known, however, what mechanism triggers the change from the interseismic' slip pattern (when the San Andreas fault is locked) to the 'co-seismic' slip pattern (when the San Andreas fault ruptures in earthquake slip). Here we use numerical simulations of the entire seismic cycle on this complex fault system to show that the San Andreas fault may be in a critical state and sensitive to small perturbations in regional compression. In particular, we find that small increases in regional compression may lock the San Andreas fault, whereas small decreases in regional compression may release the locked segment and so permit co-seismic slip. This sensitivity suggests that cyclic changes in the regional stress field resulting from plate convergence and thrust faulting in the Coast Ranges could trigger major earthquakes on the San Andreas fault.

In the past decade, it has become clear that a regional compression subnormal to the San Andreas fault system (Fig. 1a) occurs in coastal California ${ }^{5,6}$. This compression may be due to a small oblique convergence between the Pacific and the North American plates since 3.4-3.9 $\mathrm{Myr} \mathrm{ago}^{7}$, producing thrust faulting ${ }^{8-11}$ (Fig. 1b) and thrust earthquakes ${ }^{12}$ in the Coast Ranges. Several plate-motion models ${ }^{13-15}$ also show the presence of a small fault-normal component in the 'San Andreas discrepancy'. The average magnitude of this compression, inferred from stress orientation and surface heat flow, is ${ }^{5} \sim 100 \mathrm{MPa}$. Continuing, oblique plate convergence ${ }^{7}$ may cause the compression to increase slowly, whereas thrust faulting in the Coast Ranges may cause it to decrease intermittently; the magnitude of compression will therefore fluctuate with time (Fig. 1c).

The relative motion between the Pacific and the North-American plates drives the deformation in coastal California. A finite-element method is used to simulate this process. The model is a map-view layer of the seismogenic crust in central California ${ }^{16}$; it extends from Parkfield in the south to Point Arena in the north, and from the Pacific basin in the west to the Sierra Nevada foothills in the east. As the lateral dimensions of the model $(350 \mathrm{~km}$ in the east-west direction and $450 \mathrm{~km}$ in the north-south direction) are much greater than the thickness of the seismogenic layer $(10-15 \mathrm{~km})$, a thin-plate approximation may be adopted. The base of this plate coincides with a master detachment beneath the San Francisco Bay area $^{17}$. Calculation based on the crustal structure of central California $^{18}$, the geotherm of the San Francisco Bay area ${ }^{19}$, and the rheological properties of crustal minerals ${ }^{20}$ suggests that the detachment may correspond to a depth of minimum strength. Furthermore, pore pressure in many exploration wells in the region is nearly lithostatic ${ }^{21}$; thus the effective vertical stress may be small and a plane stress analysis may be appropriate. The geographical locations 